\title{
Development of Chemistry Subject Module to Improve Student's Critical Thinking in SMA Negeri 1 Pulau-Pulau Terselatan Southwest Maluku
}

\author{
Sendry Richard Dahoklory 1 , Yatim Riyanto22, Sukma Perdana Prasetya ${ }^{3}$ \\ ${ }^{1}$ Master Degree Program of Educational Technology, ${ }^{2}$ Educational Management, ${ }^{3}$ Geography Education, State University of Surabaya, Surabaya, \\ Indonesia \\ sendry17070905007@mhs.unesa.ac.id \\ *Corresponding Author \\ Whatsapp number: [+6281357364805]
}

How to Cite: Dahoklory, S., R., Riyanto, Y., Prasetya, S., P. (2019). Development of Chemistry Subject Module to Improve Student's Critical Thinking in SMA Negeri 1 Pulau-Pulau Terselatan Southwest Maluku. International Journal for Educational and Vocational Studies, 1 (8), 884-892. DOI: https://doi.org/10.29103/ijevs.v1i8.2252

\section{ARTICLE HISTORY}

Received: 11 August 2019

Revised: 11 October 2019

Accepted: 4 November 2019

\section{KEYWORDS}

Chemistry modul,

Critical Thinking

\begin{abstract}
The study aims to develop the chemistry subject module and its effectiveness in learning to improve students' critical thinking. It was conducted on the students of class XI in SMA Negeri 1 Pulau-Pulau Terselatan Southwest Maluku. It is the research of development which uses the Borg and Gall (2003) model, who adapted Dick and Carey's model named Instructional System Design which includes ten stages of development. The product of this development research is the chemistry subject module for the lesson about the colloidal system. Afterward, the developed module gets validation test using questionnaires that are given to the experts and the users, to know its feasibility to use in learning. Then, the results indicate that it is in the criteria of very feasible to use in learning. After get validation, it is analyzed using Normalized Gain (N-gain) to determine its effectiveness to improve students' critical thinking. The analysis data is obtained through one group pre-test and post-test design. Then, the result of $\mathrm{N}$-gain analysis is 0.74 categorized as "High" means that there is an increase in students' critical thinking after the application of the module. Thus it can be concluded that the chemistry subject module is suitable for use in learning, and it influences the effectiveness of learning since it can effectively improve students' critical thinking in SMA Negeri 1 Pulau-Pulau Terselatan Southwest Maluku.
\end{abstract}

This is an open access article under the CC-BY-SA license.

\section{INTRODUCTION}

Learning should have been conducted by put forward the aim to develop the knowledge and the skills for the students to deal with the development of science and technology according to the times. One of the important thing in learning is to develop and equip the students with high-level thinking, that in this case is critical thinking. Mimbs (2005) states that critical thinking is important for the students as one of the important expertise in the present day. So it is with Hasrudin (2009) explanation that critical thinking is pivotal for the students in solving the problem and making decisions scientifically. Moreover, they will more understand the concepts if the learning process is to emphasize critical thinking (Wijayanti, 2016: 106).

In the learning of science, the concept of sciences needs to be delivered with involving the students actively and directly, to make them experience the leaning activity which increase their curiosity and stimulate them to think.
One of the sciences is chemistry. This subject is learning about the natural phenomenon and its process. The nature of chemistry includes three things, namely chemistry as an attitude, chemistry as a product and chemistry as a process. Therefore, the process of learning in chemistry is including the learning of product which is the fact, the process, the principle, the theory and the learning of process. To gain knowledge, the learning of process can be conducted in the natural environment and the laboratory, while as a learning product; students are expected to know the laws, theories and their applications (Hadiwidodo, 2017).

According to the observation of chemistry subject learning process in SMAN 1 Pulau-Pulau Terselatan, showed that the active participation of students is still not enough. It was still focused on the teacher, bringing the students to less critical. The teacher present and explain the material which is only focused on their handbook while most of students have no handbook of the lesson. The use of teaching materials or learning media is not 
optimal, ineffective and efficient, and does not involve the students. Besides, according to the result of the interview with the chemistry teacher, they said that chemistry is indeed one of the subjects that is difficult to learn so it is necessary to develop appropriate teaching materials and be able to act as a medium for information transfer in learning to achieve the expected learning goals. The difficulties involved learning process are: the students are less focus so it will make the teacher in difficulty of directing them in the learning process; the students do not have the discipline of independent learning in which the tasks given are often ignored even done together so it has the same result. The teachers admitted that those difficulties exist as the result of their feebleness in developing and utilizing the exact materials in learning.

The critical thinking is the detail description of various characteristics. Those are including the process of interpretation, analysis, evaluation, inference, and self-controlling. Those processes are scientific process through learning approach inventing and suitable to the indicator of critical thinking according to Edward Glaser, that is: introduction to the problem, interpretation to the data, distillation of the data and pieces of information, formulation the conclusion, and recognition the assumptions and values (Fisher, 2003). Furthermore, Fisher (2003) explains that the important skill related to the critical thinking are in the following : (1) Have in mind the elements of the case, especially the thing related to the reasons and conclusions; (2) identify and evaluate the assumptions; (3) clarify and interpret various statement and ideas; (4) grade the level of acceptability related to the credibility and assumptions; (5) evaluate various arguments; (6) analyse, evaluate, and formulate the explanations; (7) analyse, evaluate, and describe explanations; (8) analyse evaluating, and make decisions; (9) Put two and two together and (10) make arguments..

Colloidal system is one of the subject matter of chemistry which is important to understand since it is related to the materials and industrial products for daily use. Therefore, the learning activity for this subject will be suitable to use module containing factual and contextual explanation, and at the same time allow the students to obtain knowledge from the interaction with the environment and other learning sources (Sungkono, 2003:10).

Module is prepared teaching materials to support independent learning. Those have been equipped with instructions for self-study. As stated by Sudjana and Rivai (2009: 132), module is an organized teaching program to a certain learning, completed measure tools, and a unit functioned together as a unity. The choice of module for teaching materials or teaching media is looking at: its practicability in packing, making, and fixing over the learning program; the availability of facilities or equipment to support the learning media; the compatibility of the media to the student's characteristics; the extent of student performance based on the learning objectives (Anderson, 1987:2).
Theoretically, module as a learning media with complete competence and sub-competence learning activities which emphasizes the direct learning experiences can develop the critical thinking of students. It occurs due to the critical thinking is used in the process of analysing facts, creating and organizing ideas, evaluating and inferring the conclusion of arguments for solving problems indirect learning and constructing knowledge and skills in the learning process (Chance, in Mukti: 2012). The effort to facilitate the growth of critical thinking can be conducted by giving the students worksheets which contain of case-study to be solved. As in the previous study by Pratama (2017) with objective to know the effectiveness of chemistry learning module to enhance students' critical thinking in SMAN 7 Surakarta, SMAN 1 Surakarta and SMAN 8 Surakarta, the results showed that the chemistry module can effectively enhance student's critical thinking in every school, both high, medium and low categorized.

The development of module ought to not only present the concepts and knowledge, but also it must be able to push the students to develop their critical thinking. Therefore, it should have more variation and more interactive so that it can be the solution for the teacher to develop more of students' skills. As the explanation above, it is expected that there will be a solution for student's learning problems through The Development of Chemistry Subject Module to Improve Student's Critical Thinking in SMA Negeri 1 Pulau-Pulau Terselatan Southwest Maluku.

\section{METHODS}

\subsection{Research Design}

This study is development research. In this case, it is the development of chemistry subject module for the students' grade XI of SMA Negeri 1 Pulau-Pulau Terselatan Southwest Maluku. The procedure used to refer to the learning system design of Dick \& Carey (2001, in Borg \& Gall, 2003: 570 - 572) as follows:

1. Identify the general purpose of learning

2. Analyze the learning

3. Analyze the characteristic of the students and the learning context

4. Write the specific purpose of learning

5. Develop the assesment instrument

6. Develop the learning strategies

7. Develop and select teaching materials

8. Design and develop formative evaluation

9. Revise the learning program

10. Design and develop summative evaluation

In the stage of field test to find out the effectiveness of chemistry subject module, the product will be tested using pre-experiment design, namely One Group Pre-test and Post-test Design. The research is conducted in June 2019, located in SMA Negeri 1 Pulau-Pulau Terselatan Southwest Maluku, in XI Science Class which contains 30 students. 


\subsection{Data Collection Technique}

The techniques used in data collection are questionnaires and test. The first is to validate the feasibility of developed chemistry subject module, while the last is to assess the effectiveness of the chemistry subject module in improving critical thinking. The questionnaires used are as follows:

- Questionnaire for the expert of media learning

- Questionnaire for the expert of chemistry subject

- Questionnaire for the expert of learning process planning (RPP)

- Questionnaire for the students as the user

and for the Pre-test and Post-test will use an essay test which is consist of 10 numbers of questions. It will get validity and reliability test first beforehand as a means to assess that it is a valid and reliable instrument to measure critical thinking.

\subsection{Analysis Technique}

The questionnaires will be analyzed using a statistic description by calculating the percentage of questionnaire results for the expert and the student's responds, with the formula as follows:

Percentages of assesment $=\frac{\text { Total Scores }}{\text { Maximmum Scores }} \mathrm{X} 100 \%$

According to Sugyono (2017), the criteria of assessment are in the following:

Table 1. Criteria and Percentages Questionnaire Score

\begin{tabular}{cc}
\hline Percentages & Criteria \\
\hline $80 \%-100 \%$ & Excellent, No Revision Needed \\
\hline $66 \%-79 \%$ & Good, No Revision Needed \\
\hline $56 \%-65 \%$ & Fair, Need Revision \\
\hline $40 \%-55 \%$ & Poor, Need Revision \\
\hline $0 \%-39 \%$ & Very Poor, Need Revision \\
\hline
\end{tabular}

The analysis of the chemistry subject module's effectiveness will apply Normalized Gain (N-gain) to the result of student's Pre-test and Post-test. Then the result of $\mathrm{N}$-gain will be calculated and converted to the following criteria (Hake in Nisa, 2016:83):

Table 2. The Category of N-gain Score

\begin{tabular}{cc}
\hline Limitation & Category \\
\hline $0,7<\mathrm{N}$-Gain & High \\
\hline $0,3 \leq \mathrm{N}$-gain $\leq 0,70$ & Medium \\
\hline $\mathrm{N}$-Gain $<0,30$ & Low \\
\hline
\end{tabular}

\section{RESULTS AND DISCUSSIONS}

\subsection{Results}

\subsubsection{Validation Test}

Validation test to the chemistry subject module developed aims to obtain the assessment of the experts to the feasibility of the module so that it is proved that it is ready and suitable to use in the learning activities. Furthermore, validation test is also conducted to the Learning Process Planning (RPP). The test result is in the following:

Validation of Learning Media is given to the expert on media learning to assess the chemistry subject module in the side of its graphics. The results of the assessment are in the following table 3 .

Table 3. Validation Result From The Expert of Media Learning

\begin{tabular}{|c|c|c|c|c|}
\hline \multirow{2}{*}{ Assessment Aspects } & \multirow{2}{*}{ No } & \multirow{2}{*}{ Description } & \multicolumn{2}{|c|}{ Scores } \\
\hline & & & Initial Validation & Final Validation \\
\hline \multirow{2}{*}{ Module Size } & 1 & The suitability of the module's size to the standard size (A0 - A5) & 3 & 5 \\
\hline & 2 & The suitability of of the module's size to the module contents & 3 & 5 \\
\hline \multirow{2}{*}{ Module Cover Design } & 3 & The structure and placement of the title, ilustration/picture/logo, and author's name. & 2 & 5 \\
\hline & 4 & The colour of ilustration/picture/logo, harmonious title, and clarify the function & 2 & 5 \\
\hline \multirow{3}{*}{$\begin{array}{l}\text { Typography of Module } \\
\text { Cover }\end{array}$} & 5 & The letters used are attractive and easy to read & 3 & 5 \\
\hline & 6 & $\begin{array}{l}\text { The title letter size is more dominant and proportional compared to module size, author } \\
\text { name, illustration/picture/logo }\end{array}$ & 4 & 5 \\
\hline & 7 & The module cover illustration reflects the real contents, shape, colour, size and proportion & 2 & 5 \\
\hline \multirow{6}{*}{ Book Contents Design } & 8 & The suitability of layout page design to student's characteristics & 4 & 5 \\
\hline & 9 & The consistency of layout and format between paragraphs and pages & 3 & 5 \\
\hline & 10 & The consistency of lenght space between the title with the first paragraph and the margin & 2 & 5 \\
\hline & 11 & The layout simplifies understanding of information & 2 & 5 \\
\hline & 12 & The page design makes the information clearly visible & 3 & 5 \\
\hline & 13 & The placement of illustration/pictures and its description do not intrude upon the contents & 3 & 5 \\
\hline \multirow{4}{*}{$\begin{array}{l}\text { Typography of Book } \\
\text { Contain Design }\end{array}$} & 14 & The consistency of letter used & 4 & 5 \\
\hline & 15 & The type of letter used is clearly visible and can be read & 4 & 5 \\
\hline & 16 & The letter size is balance and propotional between the title, and the material contents & 4 & 5 \\
\hline & 17 & The variation of bold, capital, and italic do not intrude upon the contents & 4 & 5 \\
\hline \multirow{2}{*}{ Content Illustration } & 18 & The Illustration/pictures simplifies understanding & 2 & 5 \\
\hline & 19 & The shape and colour of the pictures is proportional and do not intrude upon the contents. & 2 & 5 \\
\hline & & Total Scores & 52 & 95 \\
\hline
\end{tabular}

According to the calculation of the scores, the final scores in the initial sheet of validation test is in the range percentage of $55 \%$ with "Poor, Need Revision" criteria, which means that it is not recommended to use before revision. In the initial validation, the validator give some notes to revisal, that is (1) Use contrast color, (2) need to 
add more space for the margin, (3) need to enlarge the size of the pictures, (4) Add a clear and brief description to the pictures.

In the final validation, the module has been revised and obtained the final scores in the range percentage of 100\% with criteria "Excellent, No Need Revision" means that it is ready to use and no need to revise.

Validation of learning material, is given to the expert of chemistry subject to assess the feasibility of the subject matter used in the chemistry subject module. The results of the test are in the following table 4 .

Table 4. Validation Result of Subject matter

\begin{tabular}{|c|c|c|c|c|}
\hline Module Component & No & Assessment Aspects & Score & Description \\
\hline Title & 1 & The suitability of the title to the subject matter contents & 5 & Excellent \\
\hline Competence Map & 2 & The clarity of competence map & 5 & Excellent \\
\hline Learning Purpose & 3 & The learning purpose is clear and in the format $A B C D$ & 5 & Excellent \\
\hline Direction For Use & 4 & The clarity of direction for use & 4 & Good \\
\hline \multirow{4}{*}{ Subject matter Description } & 5 & $\begin{array}{l}\text { The suitability of the subject matter description to the basic competence and achievement } \\
\text { indicator }\end{array}$ & 5 & Excellent \\
\hline & 6 & The validty of the subject matter contents & 4 & Good \\
\hline & 7 & The Coherently of the subject matter presentation & 5 & Excellent \\
\hline & 8 & The illustrations/examples simplifies the concepts & 4 & Good \\
\hline Resume & 9 & The accuracy of summarizing & 5 & Excellent \\
\hline \multirow{4}{*}{ Student's Activity } & 10 & The clarity of directions for student's activity & 4 & Good \\
\hline & 11 & The suitability to the indicators & 5 & Excellent \\
\hline & 12 & The contain of critical thinking aspect & 5 & Excellent \\
\hline & 13 & The suitability to the main subject matter & 5 & Excellent \\
\hline \multirow{2}{*}{ Independent Practice } & 14 & The suitability to the learning purpose & 5 & Excellent \\
\hline & 15 & The suitability to the main subject matter & 5 & Excellent \\
\hline Feedback & 16 & The clarity of feedback directions & 4 & Good \\
\hline References & 17 & The accuracy of taking references/relevan reading source to the subject matter & 4 & Good \\
\hline \multirow{4}{*}{ Language } & 18 & The language standardization & 4 & Good \\
\hline & 19 & The suitability to the level of the students & 5 & Excellent \\
\hline & 20 & The suitability of language style to the subject matter contents & 4 & Good \\
\hline & 21 & The clarity and ease to understand the subject matter & 4 & Good \\
\hline
\end{tabular}

According to the calculation of the percentages, the final scores in this test sheet is $91,43 \%$ with criteria "Excellent, No Need Revision" means that it is ready to use and no need to revise
Quesionnaire for students as the user, user is given to find out the response of students to the chemistry subject module developed. The result is obtained from 8 responded as presented in the following table 5 .

Table 5. Quesionnaire result for student's responds

\begin{tabular}{|c|c|c|c|}
\hline \multirow{2}{*}{ No } & \multirow{2}{*}{ Assessment Aspects } & \multicolumn{2}{|c|}{ Number of Choice Respondent } \\
\hline & & Yes & No \\
\hline \multirow{2}{*}{1} & The comprehension to the messages and information & & \\
\hline & Can you understand the messages and information presented in the module? & 8 & 0 \\
\hline \multirow{2}{*}{2} & The ease of learning & & \\
\hline & Is the module making you easy to study? & 8 & 0 \\
\hline \multirow{2}{*}{3} & The simpicity of language & & \\
\hline & Can you understand the language used in the module? & 8 & 0 \\
\hline \multirow{3}{*}{4} & The attractiveness & & \\
\hline & a. With the chemistry module, will you get interested to participate in learning activities? & 8 & 0 \\
\hline & b. With the chemistry module, are you interested to study chemistry? & 7 & 1 \\
\hline \multirow{3}{*}{5} & The clarity of pictures and illustrations & & \\
\hline & a. Are the pictures presented inside the module showing a clear meaning ? & 8 & 0 \\
\hline & b. Are the illustration presented inside the module help you to understand the contents? & 7 & 1 \\
\hline & Total Scores & 54 & 2 \\
\hline
\end{tabular}

The questionnaire consists of 7 questions and it is given to the 8 groups of students. The results are 54 "Yes" and 2 "No". the "No" answer is in the side of attractiveness to learn chemistry subject, and in the Clarity of pictures and illustrations to help understanding the content of the module. Based on the total scores in the table, it can be calculated the level of responded agreement with the formula as follows:

Percentages of agreement $=\frac{\text { Total Scores }}{\text { Maximmum Scores }}$ X 100\%

The calculation result obtained agreement percentages in the amount of $96,43 \%$. The products can be said as 
suitable and right on the target if the percentage of agreement is minimally $70 \%$. Thereby, the chemistry subject module developed is following the target and can be used for further analysis.
Validation of RPP, is given to the expert both of chemistry subject and learning. The test aims to assess the feasibility of chemistry learning process planning (RPP) which is used to be the guidance in learning activities. The results are presented in Tables 6 and 7 .

Table 6. Validation result from the Chemistry Subject Expert to RPP

\begin{tabular}{clcc}
\hline No & \multicolumn{1}{c}{ Assessment Aspects } & Score & Description \\
\hline 1 & The indicator explanation refer to the basic competences & 5 & Excellent \\
\hline 2 & The Suitability of learning purpose to the basic competences & 5 & Excellent \\
\hline 3 & The clarity of learning purpose formulation (no multiple interpretations and no contains of learning outcome behavior) & 4 & Good \\
\hline 4 & The selection of teaching material is suitable to the purpose and characteristic of the students & 4 & Good \\
\hline 5 & The suitability of teaching materials to the starategies/methods/ techniques used & 5 & Excellent \\
\hline 6 & $\begin{array}{l}\text { The organization of teaching materials (the coherency and systematical of teaching materials and the suitability of time } \\
\text { allocation) }\end{array}$ & \multirow{2}{*}{ Good } \\
\hline 7 & The selection of learning source/media (suitable to the purpose, subject matter and characteristics of students) & 4 & Good \\
\hline
\end{tabular}

According to the calculation of the scores, the final scores obtained in the validation sheet from the chemistry subject expert to RPP (table 6) is in the range percentage of $88,57 \%$ with criteria "Excellent, No Need Revision" obtained in the validation sheet from the learning expert for RPP (table 7) is in the range percentage of $92,5 \%$ with criteria "Excellent, No Need Revision" means that it is ready to use without revision. means that it is ready to use without revision. Meanwhile, According to the calculation of the scores, the final scores

Table 7. Validation result from the Learning Expert to RPP

\begin{tabular}{clcc}
\hline No & \multicolumn{1}{c}{ Assessment Aspects } & Score & Description \\
\hline 1 & Indicator explanation refer to the basic competences & 5 & Excellent \\
\hline 2 & Suitability of learning purpose to the basic competences & 5 & Excellent \\
\hline 3 & Clarity of learning purpose formulation (no multiple interpretations and $\quad$ no contains of learning outcome behavior) & 4 & Good \\
\hline 4 & The Learning Objectives is in the format ABCD (Audience, Behaviour, Condition, Degree) & 5 & Excellent \\
\hline 5 & The clarity of learning stage (introduction, contents, closing) & 4 & Good \\
\hline 6 & The details of learning stage (every steps reflected the strategies/methods and time allocation for each step) & 4 & Good \\
\hline 7 & The suitability of the teaching technique to the learning objectives & 5 & Excellent \\
\hline 8 & The suitability of the learning stage to the learning objectives & 5 & Excellent \\
\hline \multicolumn{2}{c}{ Total Scores 37 } \\
\hline
\end{tabular}

\subsubsection{Effectiveness Test}

The effectiveness test of this chemistry subject module developed is given to 30 students. Then the obtained scores of each student is counted its increase nominal from pre-test and post-test using $\mathrm{N}$-gain analysis. The result can be seen in the following table 8 .

Table 8. The Result Of Student's Critical Thinking Test

\begin{tabular}{|c|c|c|c|c|c|c|}
\hline \multirow{2}{*}{ Student's Name } & \multicolumn{2}{|c|}{ Scores } & \multirow{2}{*}{ Post-pre } & \multirow{2}{*}{ Nmax-pre (100-pre) } & \multirow{2}{*}{$\mathrm{N}$-gain } & \multirow{2}{*}{ Description } \\
\hline & Pre-test & Post-test & & & & \\
\hline AA & 58 & 86 & 28 & 42 & 0,67 & Medium \\
\hline BB & 58 & 92 & 34 & 42 & 0,81 & High \\
\hline CC & 52 & 90 & 38 & 48 & 0,79 & High \\
\hline $\mathrm{DD}$ & 62 & 92 & 30 & 38 & 0,79 & High \\
\hline EE & 64 & 92 & 28 & 36 & 0,78 & High \\
\hline $\mathrm{FF}$ & 56 & 86 & 30 & 44 & 0,68 & Medium \\
\hline GG & 48 & 88 & 40 & 52 & 0,77 & High \\
\hline $\mathrm{HH}$ & 58 & 82 & 24 & 42 & 0,57 & Medium \\
\hline ॥ & 58 & 88 & 30 & 42 & 0,71 & High \\
\hline $\mathrm{JJ}$ & 52 & 88 & 36 & 48 & 0,75 & High \\
\hline KK & 54 & 90 & 36 & 46 & 0,78 & High \\
\hline
\end{tabular}




\begin{tabular}{|c|c|c|c|c|c|c|}
\hline LL & 48 & 88 & 40 & 52 & 0,77 & High \\
\hline MM & 54 & 90 & 36 & 46 & 0,78 & High \\
\hline NN & 54 & 92 & 38 & 46 & 0,83 & High \\
\hline 00 & 56 & 92 & 36 & 44 & 0,82 & High \\
\hline PP & 56 & 94 & 38 & 44 & 0,86 & High \\
\hline$Q Q$ & 50 & 88 & 38 & 50 & 0,76 & High \\
\hline $\mathrm{RR}$ & 46 & 82 & 36 & 54 & 0,67 & Medium \\
\hline SS & 46 & 84 & 38 & 54 & 0,70 & Medium \\
\hline TT & 50 & 90 & 40 & 50 & 0,80 & High \\
\hline VV & 58 & 86 & 28 & 42 & 0,67 & Medium \\
\hline$X X$ & 58 & 96 & 38 & 42 & 0,90 & High \\
\hline$Y Y$ & 54 & 86 & 32 & 46 & 0,70 & Medium \\
\hline ZZ & 54 & 80 & 26 & 46 & 0,57 & Medium \\
\hline$A B$ & 54 & 86 & 32 & 46 & 0,70 & Medium \\
\hline$A C$ & 42 & 88 & 46 & 58 & 0,79 & High \\
\hline$A D$ & 54 & 86 & 32 & 46 & 0,70 & Medium \\
\hline $\mathrm{AE}$ & 62 & 86 & 24 & 38 & 0,63 & Medium \\
\hline AF & 50 & 82 & 32 & 50 & 0,64 & Medium \\
\hline$A G$ & 46 & 90 & 44 & 54 & 0,81 & High \\
\hline Average Value & 53,73 & 88,00 & 34,27 & 46,27 & 0,74 & \\
\hline
\end{tabular}

Table 8 indicates that there is an increase in students' scores in the post-test. It can be said that the implementation of the chemistry subject module developed gives influences to the critical thinking of the students. Furthermore, the test result above is summarized in the following table 9. The summary table (table 9) indicates that the critical thinking of students

significantly increases after the learning using the module developed. As it is seen that the number of students in the "High" N-gain category is 18 with percentages $60 \%$, while the students in "medium" are 12 with percentages $40 \%$. There is no student with $\mathrm{N}$-gain under $0,30(<0,30)$ or in the "Low" category.

Table 9. The Summary of Student's Critical Thinking Test Result

\begin{tabular}{cccc}
\hline No & N-Gain Categori & Number of Students & Percentages (\%) \\
\hline 1 & High & 18 & $60 \%$ \\
\hline 2 & Medium & 12 & $40 \%$ \\
\hline 3 & Low & 0 & $0 \%$ \\
\hline
\end{tabular}

\subsection{Discussions}

As one of the educational technology domains, development can be said as the process of interpreting design to be a product. It can be a media, teaching material, and learning system to facilitate learning and upgrade the work of educational institutions. In the process of development can be use one of various approaches or development models. The development design model used in the research is the Borg and Gall (2003) model, who adapted Dick and Carey's model named Instructional System Design which consist of ten stages of development

The development of the chemistry subject module is started with the analysis of learning needs. It includes the analysis of general objectives of the learning, students' characteristic, learning context, until it produces specific objectives which must be achieved by the students after following the class. It is intended so the selection of teaching module developed is right on the development target. The module is specially developed to the subject matter about the colloidal system with the basic competences, that can group the various type of colloidal systems and describe the use of colloid in everyday life.

The chemistry subject module is one of the teaching materials that can be the right choice to give better learning experience to the students. it can be since the module is consist of chemistry subject matter packed fully and systematically with complete instruction for studying. The given examples and illustrations, tasks, practices and student's activities inside the module are intended to give contextual learning experience to the student. It offers 
various environment phenomenon related to the concept and chemistry theories which leads the students to think more about what and how those things could happen and how to facing and solving it. As stated by Daryanto (2013:9), by the contextual course related to atmosphere, tasks and students' environment, the module can ease more the learning process.

Thus, it is also developed in the respect of learning strategies planning which supports its application on learning. It is in line to the statement of Dick and Carey (2015) that is, in the selection and development of teaching materials, it must be adapted to the learning strategies planning, which the course and the pieces of information in the learning can be fully delivered to the students so the learning objectives is accomplish. The research is related to the specific learning strategy that is guide inquiry. This learning strategy as described in Learning Process Planning (RPP) emphasize on constructive learning approach, that gives direct learning experiences and require active participation of the students to contextually comprehend the chemistry phenomenon surroundings. As stated by Richardson (in Wardoyo: 2013), by constructivist learning, students create their interpretation through what they see and believe, along with the ideas and surroundings phenomenon where they experience themselves. The learning strategy as listed in the RPP has been validated and got a great assessment from the expert of the course and the learning.

The development of the module have been tested, both feasibility and effectiveness. In the beginning, the initial product got validation test through assessment of some experts, they were learning media expert to assess the graphics side and the course and the learning material experts to determine the feasibility of the subject matter inside the module. There were twice validations conducted for the learning media to produce a feasible module. In the second test, the learning media passed the test in the range of very feasible criteria. In line with the first validation, the learning material experts also gave the same scores to the criteria of feasibility. Furthermore, the group of students as the user also contributed a great response in which they could easily comprehend module contents. Thereby, the module can be said as very feasible to use for learning chemistry subject since it is feasibly developed and right on the target of learning.

The chemistry subject module developed contains the course with many instructions to make the students practice more their critical thinking. This case is intended to improve and increase their critical thinking. The improvement of this skill is important to the learning, as stated by Philips \& Bond (2004, through Nisa: 2016), it must be a significant part of even one of the most important objective in education. The development level of XI class students in SMA Negeri 1 Pulau-Pulau Terselatan is in the formal implementation. This level as stated by Piaget (through Santrock 2004: 54) is the condition where the students are capable to think in the abstract, make an alternative problem solving, and formulate some ideas. Therefore, the learning process should encourage the students to uncover concepts and principles, train them abstracting to trace and formulate the solution to the problem, and stimulate them to have the capability to make statement and questions according to their perspectives. As a result of that, the critical thinking is necessarily owned by the students and can be used in their learning.

The learning of chemistry subject which emphasize on the understanding of the concept based on the natural phenomenon surroundings need student's critical thinking to be able in interpreting those phenomenon logically followed by scientifically reasons. The chemistry subject module as a teaching material is developed through a constructivist approach with the basis that knowledge is built from learning experiences through building personal interpretations so that it strengthens student's maturity. Therefore, the contents of the module give directions about how the students can find chemistry concepts based on their surroundings phenomenon to make them able to construct the concept of chemistry in their owned perspectives and ease them in comprehending it.

The effectiveness of the chemistry module to improve the critical thinking of students have been proved by the result of the research. According to the analysis of the pre-test and post-test result, the first before the module applied, the average score was 53,73, while in the second after the application, it increased into 88,00. Then, it analysed using $\mathrm{N}$-gain and obtained 0,74 points. This point indicates the category of the effectiveness of the module applied in learning is "High". In other words, it can be said that the chemistry subject module developed is effective for users for learning and able to improve the critical thinking of the students.

The result of the research were in agreement with the study of the usage of module in learning to increase student's critical thinking by Femiceyanti (2015) which it shows that the chemistry subject module is an effective way of increasing the critical thinking of the students. So are the study of Yanti et, al (2015), reveals that it can enhance students' critical thinking. Both previous studies are in the field of science education. Thus, the match between those studies proves that the module is effective to use for learning and supports to improve student's critical thinking, especially for science-based subjects like chemistry.

\section{CONCLUSION}

The result of the questionnaire for Media Learning Expert is in the criteria of Feasible indicates that the chemistry subject module is ready and suitable to use in learning activities. In line with the first result, the result of questionnaires for the student as the user, is in the category of Strongly Agree, indicates that it is right on the target. It can be concluded that the development of the 
chemistry subject module is feasible to use in the learning activities to improve critical thinking of class XI students in SMA Negeri 1 Pulau-Pulau Terselatan Southwest Maluku.

The result of increase score analysis using $\mathrm{N}$-gain shows that there is a significant increase in the students' critical thinking as it presents in the category High. In other words, it can be said that that the development of the chemistry subject module effectively improves critical thinking of class XI students in SMA Negeri 1 Pulau-Pulau Terselatan Southwest Maluku.

\section{REFERENCES}

Anderson, R. H. (1987). Pemilihan dan Pengembangan Media Untuk Pembelajaran. Terjemahan dari judul asli: Selcting and Developing Media for instruction. Seri Pustaka Teknologi Pendidikan No 9. Jakarta: CV Rajawali.

Borg, W.R, Gall, M.D, and Gall J.P. (2003). Educational Research: An Introduction. New York: Pearson Education, Inc.

Daryanto, D. (2013). Media Pembelajaran Peranannya Sangat Penting Dalam Mencapai Tujuan Pembelajaran.Yogyakarta: Gava Media.

Facione, P. (2011). Critical Thinking. Whats It Is and Why Its Counts. Measured Reason and The California Academic Press

Femiceyanti, I. (2017). Pengembangan Modul Kimia Berbasis Inkuiri Terbimbing Pada Materi Larutan Penyangga untuk Meningkatkan Keterampilan Berpikir Kritis dan Keterampilan Proses Sains Siswa Kelas XI IPA SMA. Thesis Magister Pendidikan Sains. Universitas Sebelas Maret Surakarta. (Online). Tersedia di https://eprints.uns.ac.id/31591/ diakses pada tanggal 11 Maret 2019

Fisher, A. (2003). Critical Thinking An Introduction. New York: Cambridge University Press.

Fitriani, N.I, dan Setiawa, B. (2017). Efektivitas Modul IPA Berbasis Etnosains Terhadap Peningkatan Keterampilan Berpikir Kritis Siswa. Jurnal Penelitian Pendidikan IPA 2 (2): 71-76. (Online). Availabel online at:

https://journal.unesa.ac.id//index.php/jppipa/artic le/view/3094. Diakses pada tanggal 12 Maret 2019.

Hadiwidodo, S. (2017). Pengembangan Perangkat Pembelajaran Kimia Model Argument Driveb Inquiry Untuk Meningkatkan Keterampilan Argumentasi Dan Hasil Belajar Siswa (Tesis magister pendidikan tidak dipublikasikan). Universitas Surabaya

Khumairah, F. (2014). Pengembangan Modul Kimia Dasar Pada Materi Termokimia Berbasis Keterampilan Berpikir Kritis Untuk Mahasiswa Program Studi Pendidikan Kimia. Jurnal. (Online). Tersedia https://ejournal.unsri.ac.id/download. Diakses pada tanggal 25 Maret 2019.

Mimbs, C.A. (2005). Teaching From The Critical Thinking, Problem-Based Curricular Approach: Strategies, Challenges, And Recommendations. Journal of Family and Consumer Sciences Education, Vol. 23, No. 2: 7-18

Mukti, B. (2012). Berpikir Kritis. Bandung: Prosiding Simposium Nasional Inovasi Pembelajaran dan Sains (SNIPS). (Online). Tersedia di htttp://id.scribd.com/doc/8076824/berpikir-kritis. Diakses 12 November 2018.

Muttaqien, I. (2012). Pengembangan Perangkat Pembelajaran Model Inkuiri Terbimbing Untuk Meningkatkan Keterampilan Berpikir Kritis (Tesis magister pendidikan tidak dipublikasikan). Universitas Negeri Surabaya

Nisa, E.K. (2016). Pengembangan Perangkat Pembelajaran Fluida Statis Dengan Model Inkuiri Terbimbing Untuk Meningkatkan Keterampilan Berpikir Kritis Siswa SMA (Tesis magister pendidikan tidak dipublikasikan). Universitas Negeri Surabaya

Philips, V \& Bond, C. (2004). Undergraduates' Experiences of Critical Tinking Higher Educational Research \& Development. Journal 23 (3): 277-292

Prastowo, Andi. (2015). Panduan Kreatif Membuat Bahan Ajar Inovatif. Yogyakarta: DIV

Pratama, G.W., Ashadi. Dan Indriyanti Y. (2017). Efektifitas Penggunaan Modul Pembelajaran Kimia Berbasis Problem Based Learning (PBL) Untuk Meningkatkan Kemampuan Berpikir Kritis Siswa Pada Materi Koloid SMA Kelas XI. Prosiding Seminar Nasional Pendidikan Sains (SNPS). Hal $150-156$.

Sanjaya, W. (2008). Strategi Pembelajaran Berorientasi Standar Proses Pendidikan. Jakarta: kencana Prenada media Group.

Santrock, J.W. (2004). Psikologi Pendidikan. Edisi Kedua. Diterjemahkan dari buku aslinya Educational Psychology. Jakarta: Kencana

Sudjana N, dan Ahmad Rivai. (2009). Media Pengajaran. Bandung: Sinar Baru Algesindo

Sugiyono. (2017). Metode Penelitian Pendidikan: Pendekatan Kuantitatif, Kualitatif, dan R\&D. Bandung: Alfabeta

Wardoyo, Sigit Mangun. 2013. Pembelajaran Konstruktivisme.Bandung: Alfabeta.

Yanti, F.A., Sukarmin, Suparmi. 2015. Pengembangan Modul Pembelajaran Fisika SMA/MA Berbasis Masalah untuk Meningkatkan Keterampilan Berpikir Kritis Siswa. Pendidikan IPA. (Online),Vol. 4 No. 3.

(http://jurnal.fkip.uns.ac.id/index.php/inkuiri/article/view/ 7820, diakses 10 Juli 2019). 